\title{
Insulin-Independent Diabetes: A Defect in the Activity of Lipoprotein Lipase in Adipose Tissue
}

\author{
K. G. Taylor, D. J. Galton, and G. Holdsworth \\ Diabetes and Lipid Research Laboratory, St. Bartholomew's Hospital, West Smithfield, London, England
}

\begin{abstract}
Summary. The activity of lipoprotein lipase (E.C.3.1.1.3.) has been measured in adipose tissue from insulin-independent diabetics with hypertriglyceridaemia, non-diabetics with hypertriglyceridaemia and control patients, all of whom were obese. Although all groups showed an increase of plasma insulin after oral glucose, both the diabetic and nondiabetic hypertriglyceridaemics had impaired activities of lipoprotein lipase in adipose tissue compared to the obese normals $(\mathrm{p}<0.02, \mathrm{p}<0.03$, respectively). A course of insulin therapy (20 u.o.d.) for one week increased the activity of lipoprotein lipase extracted from adipose tissue, lowered plasma triglycerides and improved triglyceride clearance from plasma in a group of diabetics with hypertriglyceridaemia (mean plasma triglyceride $8.7 \mathrm{mmol} / \mathrm{l}$ ). Our results suggest that a feature in the development of insulin resistance in adult diabetics may be a failure of maintenance of key intracellular enzyme activities involved in lipid metabolism.
\end{abstract}

Key words: Insulin resistance, enzyme regulation, adipose tissue, lipoprotein lipase, hypertriglyceridaemia, hyperglycaemia, obesity.

The enzymatic lesions underlying the abnormalities of carbohydrate and lipid metabolism in insulin-independent diabetes are incompletely understood. An important action of insulin is to regulate levels of cellular enzymes although the mechanism of this effect is obscure. It may involve de novo enzyme synthesis by altering either the transcriptional or the translational activity of the cell $[1,2]$. We have previously reported that adipose tissue of insulin-independent diabetics have reduced activities of phospho- fructokinase (E.C.2.7.1.11) and suggested that this may limit the rate of glycolysis in this tissue [3]. Administration of subcutaneous insulin restored enzyme activities in this group of diabetics indicating that the adipose organ was unresponsive, or resistant to the action of prevailing levels of plasma insulin, but this could be overcome by additional insulin therapy [4].

As a further measure of the resistance of adipose tissue to the effect of insulin on the regulation of cellular enzymes we have studied the activity of lipoprotein lipase (E.C.3.1.1.3) in a group of obese diabetic hypertriglyceridaemic and a group of nondiabetic hypertriglyceridaemic patients. Despite a marked response of plasma insulin to an oral glucose load both in the obese controls and the patients, we found that the patient groups had reduced activities of lipoprotein lipase in adipose tissue. We suggest that a feature of insulin-independent diabetes and hypertriglyceridaemia may be the inability of insulin to maintain normal activities of key enzymes involved in carbohydrate and lipid metabolism, and this may contribute to the development of hypertriglyceridaemia and/or hyperglycaemia.

\section{Patients and Methods}

Patients were selected serially from the Diabetic and Lipid Clinics. Three groups were studied: controls, diabetic hypertriglyceridaemics and non-diabetic hypertriglyceridaemics, all of whom were obese. The diabetics were on no treatment and none subsequently required insulin therapy. The criteria for the diagnosis of diabetes was a fasting blood glucose $>6.1 \mathrm{mmol} / \mathrm{l}$, a peak blood glucose $>10 \mathrm{mmol} / 1$ and a two hour blood glucose of $>6.7 \mathrm{~mm} / 1$ after a $50 \mathrm{~g}$ oral glucose load. The control subjects were obese, but had normal glucose tolerance tests and no clinical problems requiring drug therapy. The criterion for the diagnosis of hypertriglyceridaemia was a mean fasting plasma triglyceride value of $>2 \mathrm{mmol} / 1$. Clinical details of the groups are given in Table 1 . All 


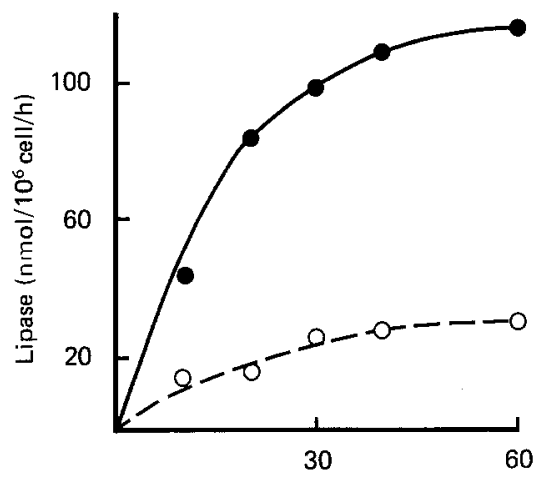

Time (mins)

Fig. 1. The release of lipoprotein lipase by adipose tissue into the incubation medium. Adipose tissue $(100 \mathrm{mg})$ was incubated in Earle's bicarbonate buffer (p.H. 7.4) with heparin $(2 \mathrm{u} / \mathrm{ml})$. The release of enzyme was measured as in Methods; points are duplicates from two patients (- $\bullet$ : a mild diabetic, fasting blood glucose $5.9 \mathrm{mmol} / \mathrm{l}, 1$ hour glucose $12 \mathrm{mmol} / 1$; $\mathrm{O} \mathrm{O}$ : a more severe diabetic, fasting blood glucose $8.8 \mathrm{mmol} / \mathrm{l}, 1$ hour glucose $17.5 \mathrm{mmol} / \mathrm{l})$

patients were admitted to the wards and after an overnight fast, blood samples were taken for plasma triglyceride and cholesterol measurements. Intralipid tolerance tests were then performed, followed by glucose tolerance tests after an interval of 24 hours. Adipose tissue $(300-600 \mathrm{mg}$ ) was obtained by a percutaneous needle biopsy [16] from the anterior abdominal wall and transported to the laboratory in saline $0.15 \mathrm{mmol} / \mathrm{l}$. A further nine diabetic hypertriglyceridaemic subjects were studied before and after a week's therapy on soluble insulin (20 u.o.d.).

\section{Plasma Lipids}

Cholesterol and triglycerides [5] were performed by standard autoanalyser methods.

The intralipid tolerance test followed the methods of Carlson and Rössner [6] where a triglyceride emulsion $0.1 \mathrm{~g}$ per kg body weight (Intralipid, Vitrum, Stockholm; 10\% soya bean emulsion) was administered intravenously as a bolus injection. Eight blood samples were obtained over the next forty minutes. The removal of the emulsion from plasma was exponential at this dose level. The rate constant for the fractional disappearance of the injected triglyceride, $\mathrm{K}_{2}$, was calculated from a least square regression line using a Wang desk computer (Model 2200).

\section{Tissue Enzyme Activities}

Two components of lipoprotein lipase activity have been measured: (i) Extractable enzyme: acetone-ether extracts of adipose tissue were prepared by homogenization in aqueous solution containing bovine plasma crystalline albumin $(20 \mathrm{mg} / \mathrm{ml})$ and then extracted with a large excess of ice cold acetone. The precipitated proteins were harvested by filtration on a Buchner funnel and subsequently washed with several volumes of acetone, followed by two extractions with cold ether. The extracts were dried in air, homogenized in $\mathrm{NH}_{4} \mathrm{Cl}$ buffer $(0.05 \mathrm{~mol} / \mathrm{l} ; \mathrm{pH} 8.6)$ and used as an enzyme source [7]. (ii) Released enzyme: adipose tissue $(100 \mathrm{mg}$ ) was incubated in Earle's bicarbonate buffer ( $\mathrm{pH} 7.4)$ at $37^{\circ}$ con- taining glucose $(5 \mathrm{mmol} / 1)$, albumin $(2.5 \mathrm{~g} / 100 \mathrm{ml})$ and heparin $(2 \mathrm{u} / \mathrm{ml})$ in a final volume of $1 \mathrm{ml}$. The amount of enzyme eluted into the incubation medium during one hour was measured.

\section{Enzyme Assays}

These were performed in a final volume of $0.5 \mathrm{ml}$ containing: human serum $(100 \mu \mathrm{l})$ to activate the enzyme, ${ }^{14} \mathrm{C}$-labelled triglyceride emulsion $(250 \mu 1)$ and enzyme source $(150 \mu l)$. The triglyceride emulsion contained: glyceryl trioleate $(0.59 \mu \mathrm{mol})$, a tracer amount of glyceryl $\left(1-{ }^{14} \mathrm{C}\right)$ trioleate $(400,000 \mathrm{dpm})$ lysophosphatidyl choline $(0.4 \mu \mathrm{mol} / 1)$ and albumin $(0.53 \mathrm{~g} / 100 \mathrm{ml})$ in Tris $\mathrm{HCl}$ buffer $(0.16 \mathrm{~mol} / 1, \mathrm{pH} 8.1)$. The substrate was sonicated at $4^{\circ} \mathrm{C}$ for 4 minutes prior to use. The enzyme reaction was started by the addition of enzyme source and stopped by the withdrawal of $200 \mu \mathrm{l}$ aliquots into Belfrage reagent $(3.25 \mathrm{ml})$. After thorough mixing and addition of $0.1 \mathrm{~mol} / 1 \mathrm{~K}_{2} \mathrm{CO}_{3}(1.05 \mathrm{ml})$ the release of ${ }^{14} \mathrm{C}$-fatty acids into the upper phase was counted as a measure of lipase activity.

\section{Miscellaneous Assays}

Plasma insulin was measured by a solid phase radioimmunoassay [11] and blood glucose by an automated glucose oxidase method [17]. Adipose cell number was obtained by digesting small pieces of adipose tissue $(20-30 \mathrm{mg})$ with collagenase at $37^{\circ} \mathrm{C}$ for approximately one hour. Aliquots of isolated fat cells were placed on siliconised glass slides and photographed with a Zeiss Jena microscope and polaroid camera attachment. The diameters of between 300 to 600 cells were determined and the mean adipocyte volume for the cells in the sample was calculated. Assuming each cell had a uniform density of triolein $(0.915 \mathrm{gm} / \mathrm{ml})$ the cell number of the tissue sample was calculated after measurement of the total triglyceride content of the tissue.

Enzyme activities are presented as means \pm SEM, either on a wet weight basis or per $10^{6}$ cells. The significance of difference was analysed by a Student's paired t-test or by a non-parametric sign test when the data were not normally distributed.

\section{Results}

The time course for the release in vitro of lipoprotein lipase activity in the presence of heparin $(2 \mathrm{u} / \mathrm{ml})$ is shown in Figure 1. Subsequent observations were made on the release of the enzyme in vitro over the course of one hour.

In both the diabetic and the non-diabetic hypertriglyceridaemic subjects there was impaired release of enzyme activity from adipose tissue compared to the obese normals (Table 1b). There was also a reduction in the acetone-ether extracted enzyme in both hypertriglyceridaemic groups. Similar results for the released and extracted lipase activity were obtained when expressed on a wet weight basis. However, the diabetic hypertriglyceridaemic patients had levels of plasma insulin under fasting conditions and at one hour after an oral glucose load which were comparable to the obese controls. It was of particular interest that the non-diabetic hypertriglyceridaemic 
Table 1. a Clinical and metabolic details of patients

\begin{tabular}{|c|c|c|c|c|c|c|c|c|c|}
\hline \multirow[t]{2}{*}{ Patient group } & \multirow[t]{2}{*}{$\mathrm{n}$} & \multirow{2}{*}{$\begin{array}{l}\text { Age } \\
y\end{array}$} & \multirow[t]{2}{*}{ Sex } & \multirow{2}{*}{$\begin{array}{l}\text { Weight } \\
\mathrm{kg} \text {. }\end{array}$} & \multicolumn{4}{|c|}{ Plasma } & \multirow[b]{2}{*}{$\begin{array}{l}\text { Intralipid } \\
\text { clearance } \\
\text { per cent/min }\end{array}$} \\
\hline & & & & & $\begin{array}{l}\text { Fasting } \\
\text { glucose } \\
\mathrm{mmol} / \mathrm{l}\end{array}$ & $\begin{array}{l}\text { Fasting } \\
\text { triglyceride } \\
\mathrm{mmol} / \mathrm{l}\end{array}$ & $\begin{array}{l}\text { Insulin } \\
\mu U / \mathrm{ml} \\
0\end{array}$ & $1 \mathrm{~h}$ & \\
\hline Obese & 12 & $43 \pm 3.6$ & $10 \mathrm{~F}$ & $103 \pm 6$ & $4.4 \pm 0.2$ & $1.5 \pm 0.1$ & $11.9 \pm 1.8$ & $66.1 \pm 7.8$ & $6.4 \pm 1.0$ \\
\hline Obese diabetic & 11 & $54 \pm 2.8$ & $8 \mathrm{M}$ & $81 \pm 3.6$ & $8.3 \pm 1.0$ & $3.4 \pm 0.7$ & $21 \pm 7.5$ & $57.5 \pm 14$ & $2.6 \pm 0.3$ \\
\hline $\mathrm{p}$ (versus obese) & & $<0.02$ & & $<0.05$ & $<0.01$ & $<0.01$ & N.S. & N.S. & $<0.01$ \\
\hline $\begin{array}{l}\text { Obese hypertriglyceri- } \\
\text { daemic } \\
\text { p (versus obese) }\end{array}$ & 9 & $\begin{array}{l}47 \pm 5 \\
\text { N.S. }\end{array}$ & $8 \mathrm{M}$ & $\begin{array}{l}89.9 \pm 9.3 \\
\text { N.S. }\end{array}$ & $\begin{array}{l}4.3 \pm 0.2 \\
\text { N.S. }\end{array}$ & $\begin{array}{l}3.8 \pm 0.6 \\
<0.01\end{array}$ & $\begin{array}{l}18.5 \pm 3 \\
<0.05\end{array}$ & $\begin{array}{l}103 \pm 14 \\
<0.05\end{array}$ & $\begin{array}{l}2.0 \pm 0.27 \\
<0.01\end{array}$ \\
\hline
\end{tabular}

Table 1. b Activities of lipoprotein lipase released by heparin ( $2 \mathrm{u} /$ ml) from adipose tissue or extracted by acetone-ether

\begin{tabular}{llc}
\hline Patient group & \multicolumn{2}{l}{ Lipoprotein lipase $\left(\mathrm{nmol} / 10^{6} \mathrm{cells} / \mathrm{h}\right)$} \\
\cline { 2 - 3 } & Extracted & Released \\
\hline Obese & $173 \pm 41$ & $191 \pm 42$ \\
Obese diabetic & $105 \pm 21$ & $90 \pm 22$ \\
p (versus obese) & $<0.02$ & $<0.05$ \\
$\begin{array}{l}\text { Obese hypertri- } \\
\text { glyceridaemic }\end{array}$ & $84.7 \pm 15$ & $70 \pm 22$ \\
p (versus obese) & $<0.03$ & $<0.02$ \\
\hline
\end{tabular}

Results are presented as means \pm standard error of the mean

patients had a marked insulin response to oral glucose but still did not maintain normal levels of either extracted or released lipoprotein lipase in adipose tissue (Table 1b).

The fractional clearance rate of Intralipid triglyceride in both diabetic hypertriglyceridaemic and non-diabetic hypertriglyceridaemic patients was significantly reduced compared to obese controls (Table 1a). The relationship between enzyme activity and intravenous triglyceride clearance was examined
(Fig. 2). The released form of the enzyme correlated more closely with the fractional clearance rate of exogenous triglyceride from the blood than did the extracted form of the enzyme (see legend to Fig. 2).

In Table $2 \mathrm{a}$ further group of nine obese diabetics with hypertriglyceridaemia (mean age 54 years; mean weight $78 \pm 2.3 \mathrm{~kg}$; mean fasting plasma glucose $6.2 \pm 0.9 \mathrm{mmol} / \mathrm{l}$ ), who showed an insulin response comparable to obese controls (fasting plasma insulin $20.2 \pm 6$; one hour after glucose 76.4 $\pm 15 \mu \mathrm{U} / \mathrm{ml}$ ), were treated for one week with insulin $(20 \mathrm{u} /$ day). This therapy significantly increased the extracted form of the enzyme in adipose tissue to activities approaching the obese controls in Table $1 \mathrm{~b}$. During insulin therapy there was also a significant decrease in the mean fasting plasma triglyceride level and a significant increase in the fractional clearance rate of Intralipid triglyceride (Table 2 ).

\section{Discussion}

Hypertriglyceridaemia is a common feature of untreated diabetes mellitus [13]; and lipoprotein lipase
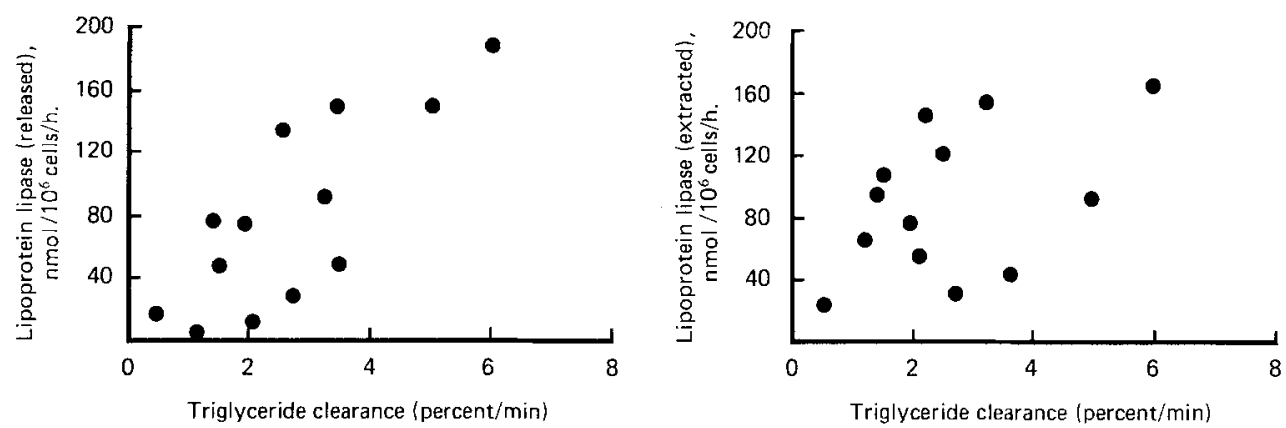

Fig. 2. Triglyceride clearance from plasma and the activity of lipoprotein lipase in adipose tissue. Intralipid clearance $\left(\mathrm{K}_{2}\right)$ is plotted against the released or extracted forms of lipoprotein lipase in adipose tissue. Correlation coefficient for released enzyme $(r)=0.7, n=13$, $\mathrm{p}<0.01$; and for extracted enzyme (r) $0.46, \mathrm{n}=13$, $\mathrm{p}$ N.S. 
Table 2. The effect of insulin therapy (20 u.o.d.) on lipoprotein lipase activity in adipose tissue

\begin{tabular}{|c|c|c|c|c|c|}
\hline \multirow{3}{*}{$\begin{array}{l}\text { Patient } \\
\text { group }\end{array}$} & \multirow[t]{3}{*}{$\mathrm{n}$} & \multicolumn{2}{|l|}{ Plasma } & \multicolumn{2}{|l|}{ Adipose tissue } \\
\hline & & \multirow{2}{*}{$\begin{array}{l}\text { Fasting } \\
\text { triglyceride } \\
\mathrm{mmol} / 1\end{array}$} & \multirow{2}{*}{$\begin{array}{l}\text { Intralipid } \\
\text { clearance } \\
\text { per cent } / \mathrm{min}\end{array}$} & \multicolumn{2}{|c|}{$\begin{array}{l}\text { Fxtracted lipoprotein lipase } \\
(\mathrm{nmol} / \mathrm{h})\end{array}$} \\
\hline & & & & Per g wet weight & per $10^{6}$ cells \\
\hline \multicolumn{6}{|l|}{ Before insulin } \\
\hline \multirow{3}{*}{$\begin{array}{l}\text { After insulin } \\
\text { therapy }(20 \mathrm{u} / \mathrm{d}) \\
\text { p value }\end{array}$} & & & & & \\
\hline & - & $5.5 \pm 0.15$ & $2.3 \pm 0.15$ & $169.2 \pm 65$ & $139 \pm 65$ \\
\hline & - & $<0.05$ & $<0.03$ & $<0.03$ & $<0.03$ \\
\hline
\end{tabular}

Table 3. Regulatory enzymes in adipose tissue of insulin independent diabetics

\begin{tabular}{|c|c|c|c|c|c|}
\hline \multirow[t]{2}{*}{ Enzyme in adipose tissue } & \multirow{2}{*}{$\begin{array}{l}\text { Possible regulatory } \\
\text { mechanism }\end{array}$} & \multirow[t]{2}{*}{ Effector } & \multicolumn{2}{|l|}{ Fnzyme activity } & \multirow[t]{2}{*}{ Reference } \\
\hline & & & Non-diabetic & Diabetic & \\
\hline $\begin{array}{l}\text { Triglyceride lipase: basal } \\
\text { activated }\end{array}$ & Covalent modification & Cyclic-AMP & $\begin{array}{l}0.19 \pm 0.01(10) \\
0.62 \pm 0.1\end{array}$ & $\begin{array}{l}0.20 \pm 0.01(11) \\
\mathrm{nmol} / \mathrm{mg} \\
0.60 \pm 0.1(13)\end{array}$ & 15 \\
\hline $\begin{array}{l}\text { Adenylate cyclase: basal } \\
\text { stimulated }\end{array}$ & Allosteric & Catecholamines & $\begin{array}{l}0.15 \pm 0.01(11) \\
1.8 \pm 0.3(10)\end{array}$ & $\begin{array}{c}0.13 \doteq 0.01(13) \\
\mathrm{pmol} / \mathrm{mg} \\
1.8 \pm 0.29(17)\end{array}$ & 15 \\
\hline Hexokinase & Allosteric & Glucose-6-phosphate & $18 \pm 2$ & $\begin{array}{c}18 \pm 1(22) \\
\mathrm{nmol} / \mathrm{mg} / \mathrm{min}\end{array}$ & 4 \\
\hline Phosphofructokinase & Allosteric/inducible & $\begin{array}{l}\text { ?insulin for } \\
\text { induction }\end{array}$ & $12 \pm 2$ & $\begin{array}{c}5 \pm 1(24) \\
\mathrm{nmol} / \mathrm{mg} / \mathrm{min}\end{array}$ & 4 \\
\hline I.ipoprotein lipase & Inducible & Insulin & $173 \quad \pm 41$ & $\begin{array}{l}105 \pm 21(11) \\
\text { nmol } / 10^{6} \text { cells }\end{array}$ & \\
\hline
\end{tabular}

Results are obtained from the literature (reference number given) and presented as means \pm S.E.M. with the number of observations enclosed within brackets

has been postulated as a rate-determining enzyme for the clearance of VLDL-triglyceride and chylomicra from plasma [8].

The decrease in the activity of lipoprotcin lipase in adipose tissue from adult diabetics in our study and the abnormalities we found in plasma triglyceride metabolism is consistent with these ideas. The obese diabetic group had mildly elevated levels of plasma triglyceride and impaired clearance of intravenous triglyceride. Diabetic patients with clevated levels of plasma triglyceride (mean $8.7 \mathrm{mmol} / \mathrm{l}$ ) were restorcd towards normal by a course of insulin therapy for one week and a concomitant increase was observed in the tissue activities of lipoprotein lipase.

In our study the diabetic hypertriglyceridaemic subjects had circulating levels of insulin during a glucose tolerance test comparable to the obese controls, but did not maintain normal lipoprotein lipase activity in adipose tissue, thus confirming studies by Pykalisto et al. [14]. We have previously reported that obese diabetic subjects did not maintain normal activities of phosphofructokinase in adipose tissue and that additional insulin therapy restored activities of phosphofructokinase [4]. In the present paper additional insulin therapy given to a group of diabetic patients with raised plasma triglycerides (mean $8.7 \mathrm{mmol} / \mathrm{l}$ ) also augmented activities of lipoprotein lipase. This suggests that unresponsiveness to insulin action can be overcome by administering more insulin. The nature of this blunted response to insulin in the diabetic adipocyte must await further elucidation of the mechanism whereby insulin augments enzyme activity. Amongst many possibilities it could be due to (a) an impaired number of cell surface receptors for insulin $[10,12]$, (b) a defect in the production of an intracellular second 'messenger' affecting translation, or (c) possibly to an abnormal apopressor regulating gene expression for de novo enzyme synthesis.

It was also of great interest that the obese nondiabetic patients with hypertriglyceridaemia had higher plasma insulins one hour after oral glucose than those with hypertriglyceridaemia and diabetes. Both groups had low activities of lipoprotein lipase in adipose tissue and there may be differences in the sensitivity of adipose tissue to the effects of insulin on 
the maintenance of activities of lipoprotein lipase and enzymes involved in glucose metabolism. The high levels of plasma insulin in the obese non-diabetic hypertriglyceridaemic subjects may be sufficient to maintain activities of enzymes involved in carbohydrate metabolism, but not lipoprotein lipase; and this may account for the appearance of hyperglycaemia and hypertriglyceridaemia in one patient group and only hypertriglyceridaemia in the other.

Insulin-independent diabetes does not appear to affect all regulatory enzymes in adipose tissue. Table 3 gives the values for several enzymes from the literature of which hexokinase, adenylate cyclase and both basal and activated triglyceride lipase are maintained at similar activities in obese diabetic and nondiabetic tissues. By contrast activities of phosphofructokinase and lipoprotein lipase have now been found to be reduced in insulin-independent diabetes.

Acknowledgements. Grateful thanks for financial support are due to the Medical Research Council, UK (KGT) and to the Joint Research Board of St. Bartholomew's Hospital, London (GH).

\section{References}

1. Wool, I. G., Stirewalt, W. S., Kurihara, K., Low, R. B., Bailey, P., Oyer, D.: Mode of action of insulin in the regulation of protein biosynthesis in muscle. Recent Prog. Horm. Res. 24, 139-152 (1968)

2. Manchester, K. L.: In: The biological basis of medicine, 2. Bittar, E. E., Bittar, N. (Ed.), p. 221. London: Academic Press 1968

3. Galton, D. J., Wilson, J.P. D.: Glycolytic enzymes in human adipose tissue of adult diabetics. Br. Med. J. 1970 III, 444-445

4. Galton, D. J., Wilson, J.P. D.: The effect of starvation and diabetes on glycolytic enzymes in human adipose tissue. Clin. Sci. 41, 545-553 (1971)

5. Cramp, D., Robertson, G.: The fluorometric assay of triglyceride by a semiautomated method. Anal. Biochem. 25, 246-251 (1968)
6. Carlson, L. A., Rössner, S.: A methodological study of an intravenous fat tolerance test with Intralipid emulsion. Scand. J. Clin. Lab. Invest. 29, 271-280 (1972)

7. Nilsson-Ehle, P., Tornqvist, H., Belfrage, P.: Rapid determination of lipoprotein lipase activity in human adipose tissue. Clin. Chim. Acta 42, 383-390 (1972)

8. Robinson, D. S.: The function of plasma triglycerides in fatty acid transport. In: Comprehensive biochemistry, vol. 18. Florkin, M., Stotz, E. H. (eds.). Amsterdam: Elsevier 1970

9. Crofford, O. B., Minemura, T., Kono, T.: Insulin-receptor interaction in isolated fat cells. Adv. Enzyme Regul. 8, 219-238 (1969)

10. Freychet, P., Laudat, M. H., Rosselin, G., Kahn, C. R., Gordon, P., Roth, J.: Impairment of insulin binding to the fat cell membrane in the obese hyperglycaemic mouse. FEBS Lett. 25, 339-342 (1972)

11. Herbert, V., Lau, K.S., Gottlieb, C.W., Bleicher, S. J.: Coated charcoal immunoassay of insulin. J. Clin. Endocrinol. Metab. 25, 1375-1384 (1965)

12. Bar, R. S., Gorden, P., Roth, J., Kahn, R., De Meyts, P.: Fluctuations in the affinity and concentration of insulin receptors on circulating monocytes of obese patients. Effects of starvation, refeeding and dieting. J. Clin. Invest. 58, 1123-1135 (1976)

13. Nikkilä, E. A., Kekki, M.: Plasma triglyceride transport kinetics in diabetes mellitus. Metabolism 22, 1-22 (1972)

14. Pykalisto, O. J., Smith, P. H., Brunzell, J. D.: Determinants of human adipose tissue lipoprotein lipase. J. Clin. Invest. 56, 1108-1117 (1975)

15. Reckless, J. P. D., Galton, D. J.: Catecholamine receptor sensitivity and the regulation of lipolysis in adult diabetes. Diabetologia 12, 351-358 (1976)

16. Diengott, D., Kerpel, S.: New type of needle for obtaining large samples of human adipose tissue. J. Lipid Res. 8, 58-60 (1967)

17. Brown, M. E.: Ultra-micro sugar determinations using 2, 9-dimethyl-1, 10-phenanthroline hydrochloride (neocuproine). Diabetes 10, 60-62 (1961)

Received: November 1, 1978, and in revised form: February 12, 1979

Dr. D. J. Galton

Diabetes and Lipid Research Laboratory

St. Bartholomew's Hospital

London EC1

England 